\title{
Using the plate-creep test to determine the impact strength properties of concrete
}

\author{
Murat Gökçe \\ Amasya University, Architecture Faculty, Architecture Department, Amasya, Turkey \\ Corresponding Author: murat.gokce@amasya.edu.tr
}

$\begin{array}{ll}\text { Submitted } & : 30 / 05 / 2021 \\ \text { Revised } & : 29 / 09 / 2021 \\ \text { Accepted } & : 11 / 10 / 2021\end{array}$

\begin{abstract}
The paper aims to design a concrete against repetitive impact and abrasion resistance. Macro/micro steel fibers and two types of crushed stone based on limestone and corundum as aggregate were used in concrete mixtures. Impact test device has been modified, designed, and used for impact strength testing of concrete. The usability of the plate-creep test in determining the impact strength of concrete was also investigated. According to the test results, a high correlation was found between the abrasion, impact resistance tests, and the creep test.
\end{abstract}

Keywords: Impact resistance; Energy absorption capacity; Corundum and limestone aggregates; Abrasion strength; Macro-micro steel fibers.

\section{INTRODUCTION}

Fiber reinforced cement composite has become a widely applied versatile material in the construction industries due to its various advantages (Bentur and Mindess 2006; Wongprachum et al., 2018). These include, but are not limited to, bridging and sealing cracks, toughness and tensile stress capacity, reducing the need for steel reinforcement and workers, repairing concrete structures, and providing a durable and permanent solution (Wongprachum et al., 2018; Banthia et al., 2014; Banthia and Sappakittipakorn 2007; Banthia and Gupta 2006). Due to these benefits, the fibers prevent degradation of cementitious matrices (Wongprachum et al., 2018). Ultra-high performance fiberreinforced concrete developed in the mid-1990s has been recognized as one of the most promising building materials for architectural or individual structures subjected to earthquakes, shocks, and extreme loads (Yoo and Banthia 2017). The fiber-reinforced cement composite is suitably used for structures under flexibility or stress, as it prevents crack propagation and can expand the crack by fiber bridging (Yoo et al. 2017). Various types of fiber-reinforced cement-based materials, including metallic, polymeric, carbon, glass, nylon, and waste rubber fibers, have been successfully developed and effectively applied for infrastructure (including buildings, tunnels, and bridges) due to the benefits of limiting crack propagation and widening through fiber bridging (Yoo et al. 2019). In addition, increasing the static tensile and bending performance of ultra-high performance fiber reinforced concrete has been successfully achieved by using deformed steel fibers (hooked or twisted) or by 
increasing the aspect ratio of plain steel fibers without increasing the fiber volume content (Yoo et al., 2017; Richard and Cheyrezy 1995; Wille et al., 2011; Yoo et al., 2015). Concrete and fiber-reinforced concrete are very sensitive to loading speeds (i.e., strain or strain rates) that exhibit completely different behavior under impact loads compared to static loads, so the technology needs a new study on impact strength (ACI 201). In this study, the use of slab creep test to determine the impact strength of concrete was investigated.

\section{MATERIALS AND METHOD}

\section{Materials}

\section{Aggregate}

In the study, limestone and corundum aggregates with a maximum granule size of $12 \mathrm{~mm}$, whose physical properties are shown in Table 1, were used as aggregates. The density of limestone-based aggregate is $2.70 \mathrm{~g} / \mathrm{cm} 3$, and the density of corundum aggregate is $4.55 \mathrm{~g} / \mathrm{cm} 3$.

Table 1. Physical properties of limestone aggregate and corundum aggregate.

\begin{tabular}{|c|c|c|c|c|}
\hline \multirow{2}{*}{ Physical properties } & \multicolumn{2}{|c|}{ Limestone Aggregate } & \multicolumn{2}{c|}{ Corundum Aggregate } \\
\cline { 2 - 5 } & $\begin{array}{c}\text { Fine } \\
\text { Aggregate }\end{array}$ & $\begin{array}{c}\text { Coarse } \\
\text { Aggregate }\end{array}$ & $\begin{array}{c}\text { Fine } \\
\text { Aggregate }\end{array}$ & $\begin{array}{c}\text { Coarse } \\
\text { Aggregate }\end{array}$ \\
\hline Sieve Diameter & $0-4 \mathrm{~mm}$ & $4-8 \mathrm{~mm}$ & $0-4 \mathrm{~mm}$ & $4-8 \mathrm{~mm}$ \\
\hline Density $\left(\mathrm{g} / \mathrm{cm}^{3}\right)$ & 2.65 & 2.65 & 4.10 & 4.10 \\
\hline Water Absorption $(\%)$ & 1.80 & 0.75 & 0.10 & 0.05 \\
\hline
\end{tabular}

\section{Chemical Additive}

In this study, a polycarboxylate-based hyperplasticizer admixture has been used to preserve the consistency of the fresh concrete for 60 minutes and to settle in the mold with its own weight, considering the application conditions. The density of polycarboxylate-based superplasticizer is $1.11 \mathrm{~g} / \mathrm{cm}^{3}$ and $\mathrm{pH} 5.7$ and solid matter $29 \%$.

\section{Blast Furnace Slag (BFS)}

The blast furnace slag with a density of $3 \mathrm{gr} / \mathrm{cm}^{3}$ and a specific surface area of $4785 \mathrm{~cm}^{2} / \mathrm{gr}$ was used in this study. The chemical analysis of blast furnace slag is shown in Table 2.

\section{Calcite (Ca)}

The maximum grain size of calcite use in the study is 75 microns. Calcite has a density of 2.72 $\mathrm{g} / \mathrm{cm}^{3}$ and a surface area of $4760 \mathrm{~cm}^{2} / \mathrm{g}$. The chemical properties of calcite are given in Table 2 . 
Table 2. Chemical properties of blast furnace slag and calcite.

\begin{tabular}{|c|c|c|c|c|c|c|c|c|c|c|c|c|c|}
\hline $\begin{array}{l}\stackrel{\mathscr{U}}{D_{0}} \\
\stackrel{0}{0} \\
0\end{array}$ & $\mathrm{SiO}_{2}$ & $\mathrm{CaO}$ & $\mathrm{Al}_{2} \mathrm{O}_{3}$ & $\mathrm{MgO}$ & $\mathrm{MnO}$ & S & $\mathrm{Fe}$ & $\mathrm{K}_{2} \mathrm{O}$ & $\mathrm{Na}_{2} \mathrm{O}$ & $\mathrm{TiO}_{2}$ & $\mathrm{Fe}_{2} \mathrm{O}_{3}$ & $\mathrm{SO}_{3}$ & $\mathrm{Ca}$ \\
\hline $\begin{array}{l}\frac{0}{0} \\
\tilde{c} \\
\frac{1}{\infty}\end{array}$ & 38.5 & 36.31 & 9.98 & 7.8 & 2.92 & 0.63 & 0.66 & 1.38 & 0.23 & 1.31 & - & - & - \\
\hline$\overbrace{0}^{\infty}$ & 0.01 & 53.94 & 0.07 & 1.93 & - & - & - & 0.13 & 0.06 & - & 0.05 & 0.01 & 44.54 \\
\hline
\end{tabular}

\section{Cement}

The properties of the cements CEM I 42.5 and CEM I 52.5 are given in Table 3.

Table 3. Physical and chemical properties of CEM I 42.5 and 52.5 cement.

\begin{tabular}{|c|c|c|c|c|c|}
\hline & & \multirow{2}{*}{ Physical Properties } & CEM I 42.5 & CEM I 52.5 & \multicolumn{3}{|c|}{ Chemical Properties } \\
\cline { 4 - 6 } & & & $\begin{array}{c}\text { Content } \\
(\%)\end{array}$ & CEM I 42.5 & $\begin{array}{c}\text { CEM I } \\
52.5\end{array}$ \\
\hline Density $\left(\mathrm{g} / \mathrm{cm}^{3}\right)$ & 3.1 & 3.15 & $\mathrm{SO}_{3}$ & 2.8 & 2.57 \\
\hline Blaine $\left(\mathrm{cm}^{2} / \mathrm{g}\right)$ & 3355 & 4654 & $\mathrm{SiO}_{2}$ & 20,5 & 21,6 \\
\hline 2 days strength $(\mathrm{MPa})$ & 27.3 & 29.5 & $\mathrm{Al}_{2} \mathrm{O}_{3}$ & 5.27 & 4,28 \\
\hline 28 days strength $(\mathrm{MPa})$ & 51.7 & 61.5 & $\mathrm{CaO}_{2}$ & 62.2 & 65,8 \\
\hline Volume expansion $(\mathrm{mm})$ & 1 & 1 & $\begin{array}{c}\mathrm{Na}_{2} \mathrm{O} \\
+\mathrm{K}_{2} \mathrm{O}\end{array}$ & 0.82 & 0.49 \\
\hline
\end{tabular}

\section{Macro and Micro Steel Fibers}

In concrete produced using limestone aggregates, the total fiber amount was kept constant as 110 $\mathrm{kg} / \mathrm{m}^{3}$ (macro + micro steel fiber). The fiber amount in concrete produced with corundum aggregate was kept constant at $100 \mathrm{~kg} / \mathrm{m}^{3}$ (macro + micro steel fiber). Brass coated micro steel fiber with a diameter of $0.25 \mathrm{~mm}$, a length of $6 \mathrm{~mm}$, and a tensile strength of $2100 \mathrm{~N} / \mathrm{mm}^{2}$ was used to strengthen the surface of the fine material paste and prevent micro cracks (Figure 1a). A macro steel fiber of 35 $\mathrm{mm}$ in length, $0.75 \mathrm{~mm}$ in diameter, and $1200 \mathrm{~N} / \mathrm{mm}^{2}$ tensile strength was used (Figure $1 \mathrm{~b}$ ) in this study. 

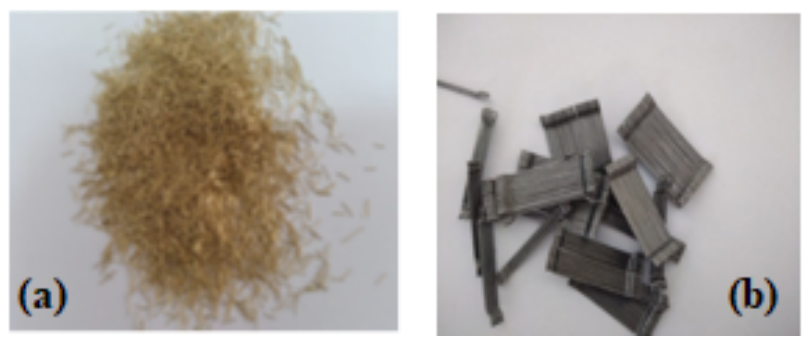

Figure 1. (a) Brass coated micro steel fiber and (b) macro steel fiber.

\section{Metot}

In order to solve the segregation problem and increase the viscosity of self-compacting concrete prepared by using polycarboxylate-based plasticizer additive, the amount of materials smaller than 100 microns was taken as at least $700 \mathrm{~kg}$ (cement + calcite + blast furnace slag) in $1 \mathrm{~m}^{3}$. In concrete mixtures made with limestone aggregate, the cement type was chosen as CEM I 42.5, and cement dosage was taken as 520 and $560 \mathrm{~kg} / \mathrm{m}^{3}$. In concrete mixes made with corundum aggregate, the cement type is CEM I 52.5, and the cement dosage is $475 \mathrm{~kg} / \mathrm{m}^{3}$. The amount of calcite and blast furnace slag in all concrete mixtures was kept constant as $150 \mathrm{~kg} / \mathrm{m}^{3}$ and $120 \mathrm{~kg} / \mathrm{m}^{3}$, respectively. The amount of water in concrete mixes is adjusted to have a spread of at least $650 \mathrm{~mm}$. The amount of polycarboxylate-based admixture has been fixed as $3 \%$ of the cement dosage in all concrete mixtures.

\section{Concrete Mix Ratios}

The concrete mix proportions prepared in this study are given in Table 4. 0-4 mm limestonebased aggregate was added to corundum aggregate concrete in order to solve the problem of high density of corundum aggregate and segregation that may occur in concrete.

Table 4. Concrete mix ratios produced with limestone aggregates and corundum aggregates.

\begin{tabular}{|c|c|c|c|c|}
\hline Materials & $\begin{array}{c}\text { Limestone 1 } \\
\left(\mathrm{kg} / \mathrm{m}^{3}\right)\end{array}$ & $\begin{array}{c}\text { Limestone 2 } \\
\left(\mathrm{kg} / \mathrm{m}^{3}\right)\end{array}$ & $\begin{array}{c}\text { Corundum 1 } \\
\left(\mathrm{kg} / \mathrm{m}^{3}\right)\end{array}$ & $\begin{array}{c}\text { Corundum 2 } \\
\left(\mathrm{kg} / \mathrm{m}^{3}\right)\end{array}$ \\
\hline Cement Type & CEM I 42.5 & CEM I 42.5 & CEM I 52.5 & CEM I 52.5 \\
\hline Dosage of the cement & 190 & 560 & 475 & 475 \\
\hline Water & 750 & 700 & 580 & 175 \\
\hline $0-4$ mm fine aggregate (limestone) & -- & -- & 600 & 600 \\
\hline $0-4$ mm fine aggregate (corundum) & 600 & 602 & 530 & 530 \\
\hline 4-8 mm coarse aggregate & 150 & 150 & 150 & 150 \\
\hline Calcite & & & & \\
\hline
\end{tabular}




\begin{tabular}{|c|c|c|c|c|}
\hline Blast furnace slag & 120 & 120 & 120 & 120 \\
\hline Macro steel fiber & 70 & 80 & 40 & 60 \\
\hline Micro steel fiber & 40 & 30 & 60 & 40 \\
\hline Chemical additive & 15.6 & 16.8 & 14.2 & 14.2 \\
\hline Spread diameter for t=0 min (cm) & 67 & 66 & 68 & 67 \\
\hline Spread diameter for t=60 min (cm) & 68 & 68 & 68 & 69 \\
\hline Theoretical unit volume weight & 2455.6 & 2455.8 & 2744.2 & 2744.2 \\
\hline
\end{tabular}

\section{Compressive Strength Test}

The prepared concrete cubes of $150 \times 150 \times 150 \mathrm{~mm}$ were subjected to the compressive strength test in accordance with EN 12390-3 (EN 12390-3 2019).

\section{Flexural Strength Test}

Concrete beam samples were tested in accordance with EN 12390-5 (EN 12390-5 2019). Beam samples with dimensions of 100x100x500 mm were tested by loading at a speed of $1 \mathrm{kN} / \mathrm{sec}$.

\section{Abrasion Resistance Test}

Concrete specimens of 100x100x100 mm dimensions are subjected to abrasion test. Abrasion resistance was carried out on concrete samples on the 28th day in accordance with the principles specified in ASTM C944/C944M (ASTM C944 2019). The samples were exposed to the abrasive wheels at $200 \mathrm{rpm}$ under the weight 3 times at 2 minute intervals. At the end of the experiment, the weight loss by mass in the samples was measured, and the results were calculated as "\% weight loss."

\section{Creep Test}

The creep test was conducted to determine the energy absorbed in concrete. The toughness energy was found from the area under the curve by drawing load-deflection graphs of the slab samples. The test was carried out according to EN 14488-5 (EN14488-5 2006) standard on 600x600x100 mm concrete slabs.

Figure 2 shows the testing of slab samples. Slab samples were loaded with 100x100 mm dimensions from the middle point and the deformation up to $10 \mathrm{~mm}$ at the bottom of the slab was measured. Load-deflection graphs of the slab samples were drawn, and the toughness energy was found from the area under the curve. 


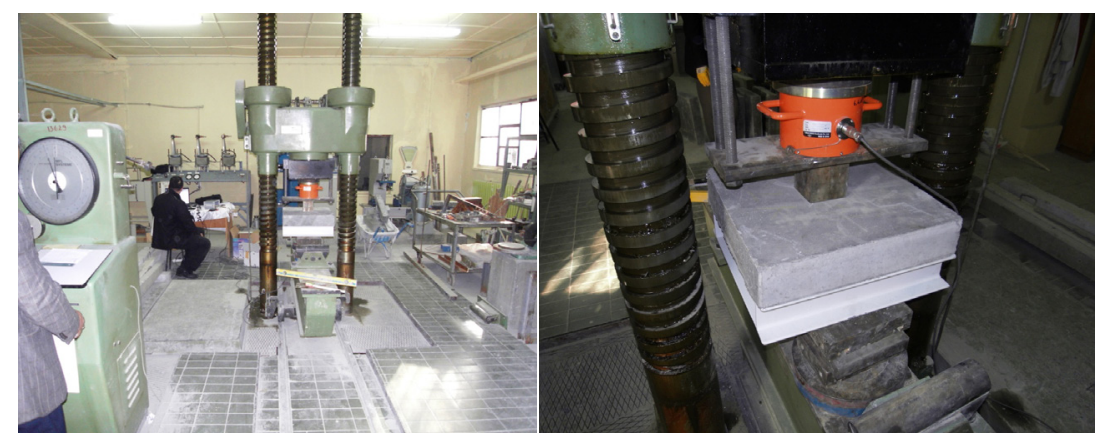

Figure 2. The testing of slab samples.

\section{Energy Absorption Capacity}

In this study, the energy absorption capacities of fiber reinforced concrete were determined by testing according to EN 14488-5 (EN14488-5 2006) standard on 600x600x100 mm concrete slabs. The energy absorption capacity was found from the area under the curve by drawing the energydeflection graph with the amount of the energy found (Figure 8). The EN 14487-1 (EN14487-1 2006) standard divides the energy absorption performance of the slab into 3 groups as $500 \mathrm{~J}, 700 \mathrm{~J}$, and 1000 $\mathrm{J}$ for the deformation of the slab up to $25 \mathrm{~mm}$.

\section{Impact Resistance Test}

The impact test device has been modified and built according to The South African Bureau of Standards (SABS 541) Impacting Steel Balls Abrasion Test standard (South African Bureau of Standards 2012). Concrete samples with a surface area of 270x270 mm and a height of $100 \mathrm{~mm}$ were prepared for the impact test. Before the test, each sample was weighed, and its weight recorded. 25 iron balls with a total mass of $12500 \mathrm{gr}$ and a diameter of $45 \mathrm{~mm}$ were placed in the impact test device. The prepared concrete samples were tested for 12 hours in the impact test device with a speed of $60 \pm$ $2 \mathrm{rpm}$ (Figure 3). The test device was rotated 6 hours on the right axis and 6 hours on the left axis. Then, the weight of each sample was weighed after the experiment and recorded. The weight loss before and after the test was found in percent and defined as the percent weight loss.
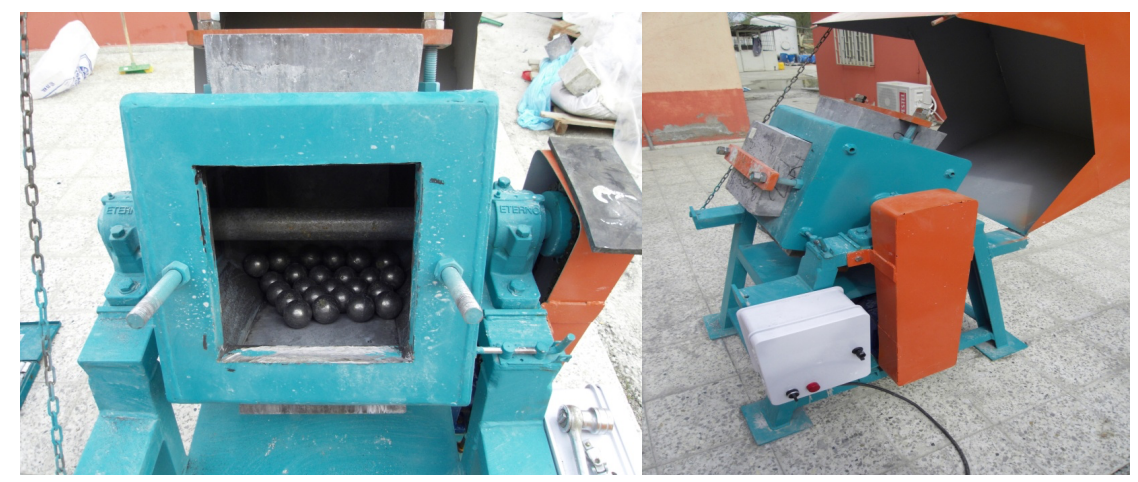

Figure 3. Impact Resistance Test Device. 


\section{EXPERIMENT RESULTS}

\section{Compressive and Flexural Strength Test Results}

Compressive strength test results of concrete samples are given in Table 5. Compressive strengths of prepared concrete are between 80 and $93 \mathrm{MPa}$. As a result of the use of CEM I 52.5 cement in concrete produced with corundum aggregate, the low water/cement ratio, and the density of the concrete being approximately $2744 \mathrm{~kg} / \mathrm{m}^{3}$, the compressive strength results were higher than the concrete produced with limestone-based aggregate. Beam flexural test results (Table 5) are very close for concrete with limestone and corundum aggregates.

Table 5. Compressive and flexural strength results of concrete samples on 28 days.

\begin{tabular}{|c|c|c|}
\hline Mixtures & Compressive Strength (MPa) & Flexural Strength (MPa) \\
\hline Limestone 1 & 80.15 & 11.23 \\
\hline Limestone 2 & 84.30 & 11.69 \\
\hline Corundum 1 & 90.80 & 11.65 \\
\hline Corundum 2 & 93.58 & 11.88 \\
\hline
\end{tabular}

\section{Abrasion Test Results}

When the abrasion test results were made according to the ASTM C944 (ASTM C944 2019) standard (test period 2 minutes for one side of the sample), it was observed that the abrasion was only on the cement paste surface. There was a mass loss in concrete samples between 0.5 and $1 \mathrm{~g}$ as a result of abrasion. These values did not give correct results because the abrasion could not reach the aggregate surface. The duration of the test has been increased to 12 minutes in order to create abrasion on the aggregate surface. Abrasion was observed on aggregates after 12 minutes. Abrasion test results of the samples are given in Table 6 . The weight loss was $0.38-0.36 \%$ for concrete produced with corundum aggregates, while it was found to be $0.65-0.60 \%$ in concrete containing limestone aggregates. It has been determined that concrete produced with corundum aggregates has high resistance to abrasion.

Table 6. Results of the Abrasion Test.

\begin{tabular}{|c|c|c|c|c|}
\hline Mixtures & Limestone 1 & Limestone 2 & Corundum 1 & Corundum 2 \\
\hline Weight loss (\%) & 0.65 & 0.60 & 0.38 & 0.36 \\
\hline
\end{tabular}




\section{Results of the Creep Test and Energy Absorption Capacity Test}

In the energy absorption capacity test, it was observed that there was a significant increase in energy absorption capacity as the macro steel fiber dosage increased in concrete mixtures produced with limestone and corundum aggregates. In concrete produced with limestone aggregate, an increase of 192 joules in toughness energy was created with the increase in the volume of cement paste and macro steel fiber for the creep test. In concrete produced with corundum aggregate, the volume of cement paste was kept constant, and the toughness energy of 12 joules increased with the increase in the rate of macro steel fiber. The limestone 2 concrete mix design made with limestone aggregate with the highest macro steel fiber content $\left(80 \mathrm{~kg} / \mathrm{m}^{3}\right)$ has the highest toughness energy with 955 joules. As can be seen from the results, the increase in the rate of macro steel fiber has led to an increase in toughness energy in concrete. The deformation measurement that occurs in concrete slabs is shown in Figure 4.

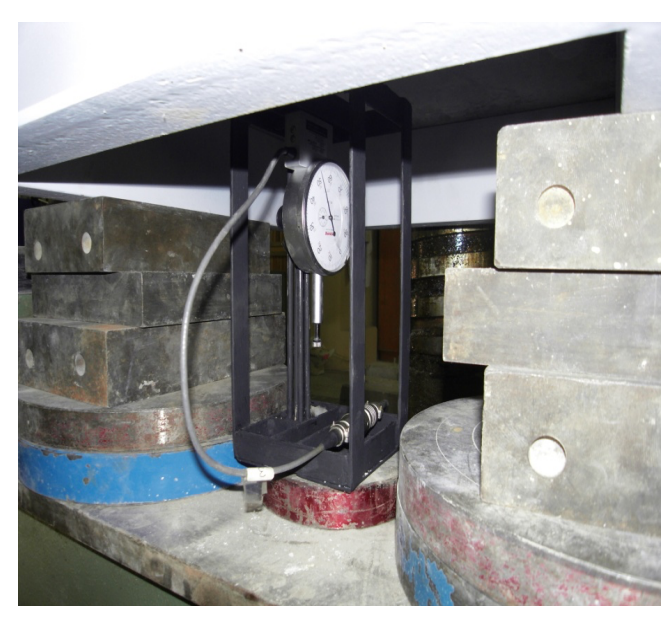

Figure 4. Measurement of deformation in slab samples.

Load-deflection graphs of concrete produced with limestone and corundum aggregates are given in Figures 5, 6, 7, and 8. The toughness energy was found from the area under the load-deflection curve (Table 7).
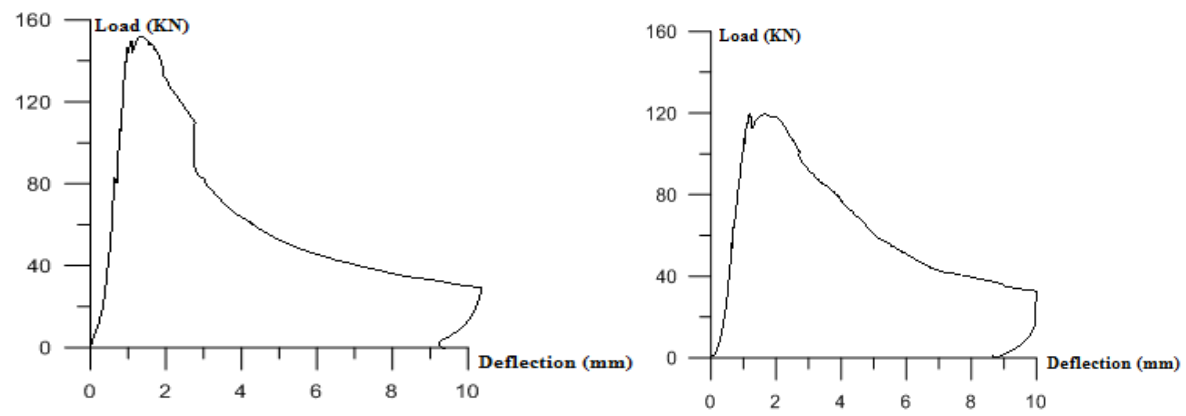

Figure 5. Load-Deflection graphs for concrete slabs of Limestone 1. 

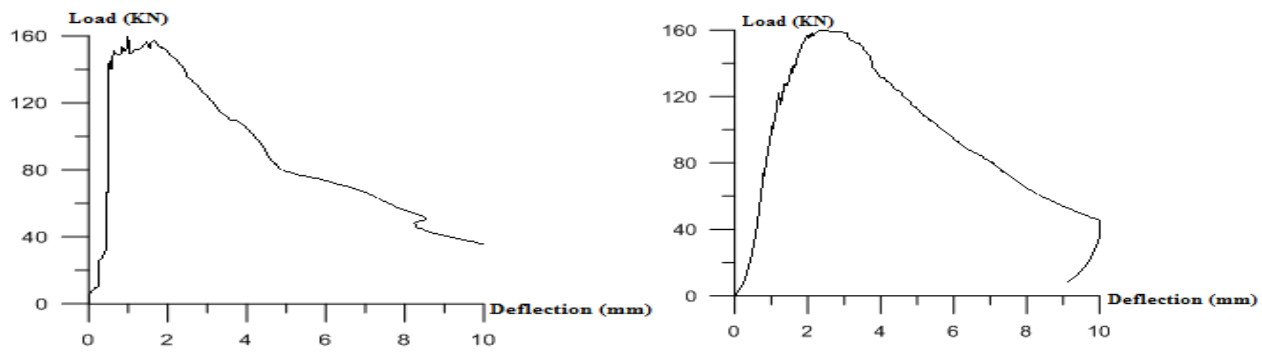

Figure 6. Load-Deflection graphs for concrete slabs of Limestone 2.
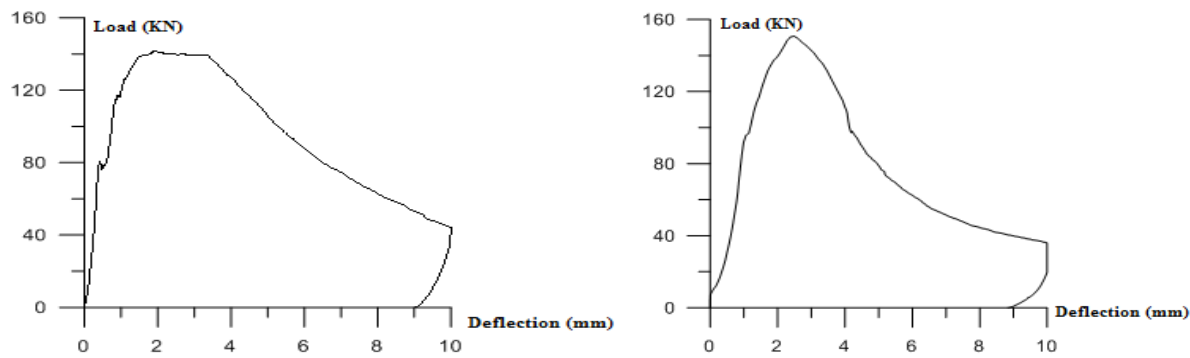

Figure 7. Load-Deflection graphs for concrete slabs of Corundum 1.
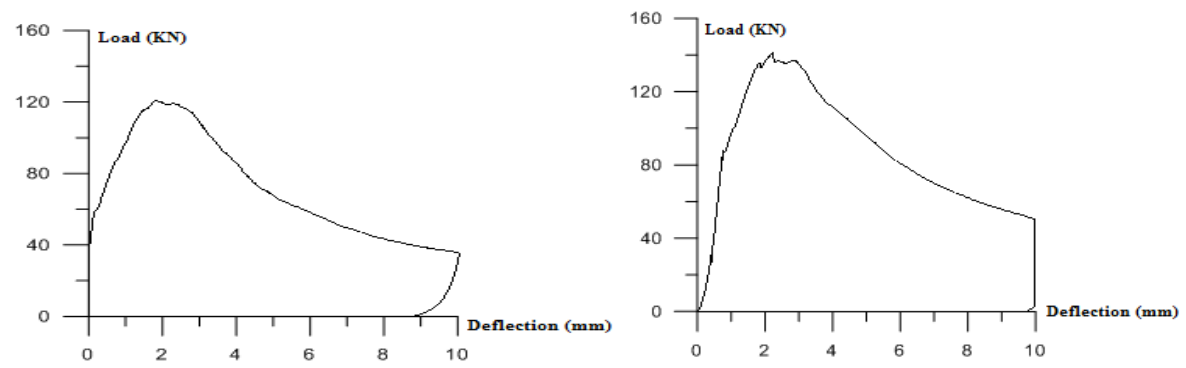

Figure 8. Load-Deflection graphs for concrete slabs of Corundum 2

Table 7. Toughness energy of concrete slabs.

\begin{tabular}{|c|c|c|c|c|}
\hline Mixtures & Limestone 1 & Limestone 2 & Corundum 1 & Corundum 2 \\
\hline Toughness Energy (Joule) & 763 & 955 & 800 & 812 \\
\hline
\end{tabular}

Energy-deflection graphs were drawn with the toughness energy found. Energy absorption capacities from the area under the energy-deflection curve were found in Figures 9 and 10. 


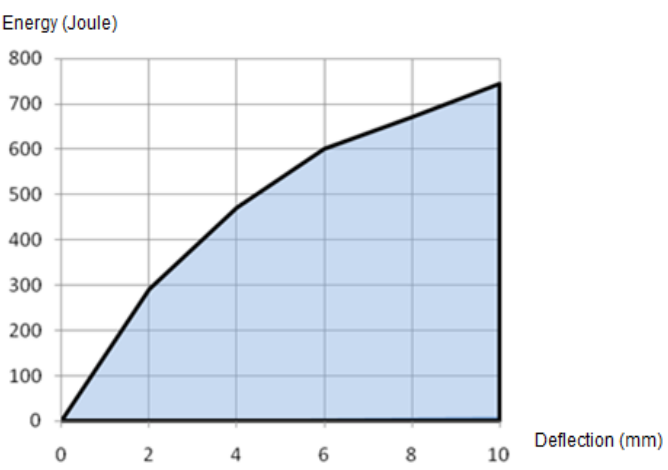

Limestone 1

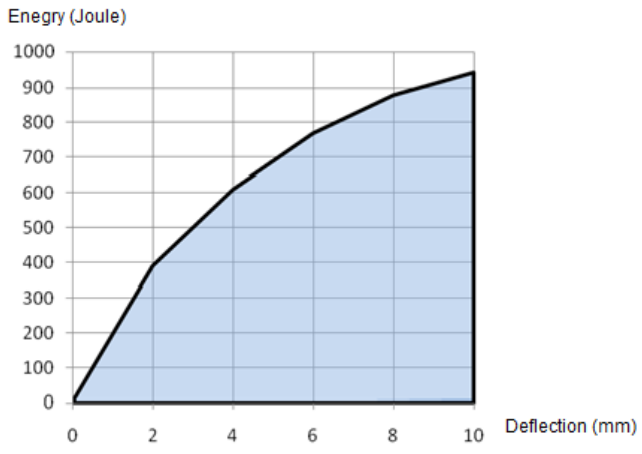

Limestone 2

Figure 9. Energy-deflection graphs of limestone aggregate concrete.

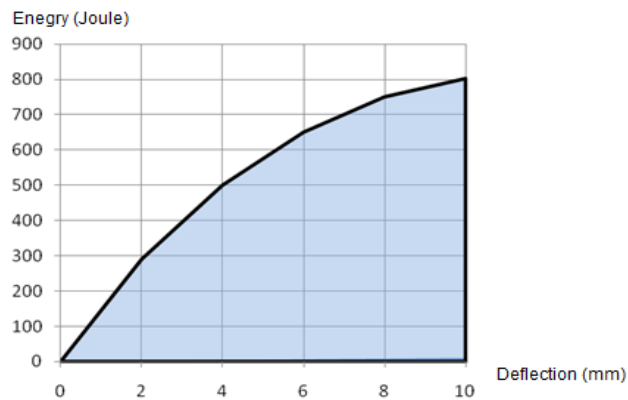

Corundum 1

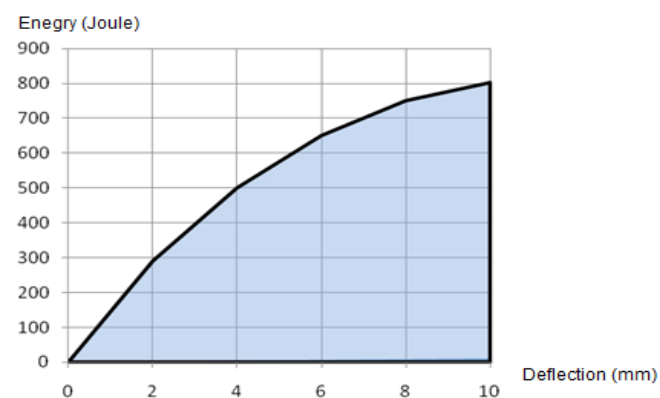

Corundum 2

Figure 10. Energy-deflection graphs of corundum aggregate concrete.

As can be seen in Table 8, the concrete with the highest energy absorption capacity with the Limestone 2 concrete mixture with 6296 joules was determined.

Table 8. Energy absorption capacity of concrete slabs.

\begin{tabular}{|c|c|c|c|c|}
\hline Mixtures & Limestone 1 & Limestone 2 & Corundum 1 & Corundum 2 \\
\hline Energy absorption Capacity & $4873 \mathrm{~J}$ & $6296 \mathrm{~J}$ & $5190 \mathrm{~J}$ & $5212 \mathrm{~J}$ \\
\hline
\end{tabular}

\section{Impact Resistance Test}

Less weight and volume loss occurred in limestone aggregate concrete with a macro steel fiber amount of 70 and $80 \mathrm{~kg} / \mathrm{m}^{3}$ in the impact resistance test. When limestone and corundum aggregate concrete were subjected to impact resistance test at the same time, 4 and $2.9 \%$ weight loss occurred in 
limestone 1 and limestone 2 concrete, respectively, while 7.5 and $6.3 \%$ weight loss occurred in corundum 1 and corundum 2 concrete (Table 9).

The macro steel fiber dosage used in limestone aggregate concrete was kept higher than concrete with corundum aggregate. The high macro steel fiber content has absorbed the energy resulting from the impact on the surface of the concrete by spreading it more homogeneously throughout the concrete. Less weight loss occurred in concrete prepared with limestone aggregates as a result of the impact test. It was determined that the least weight loss $(2.9 \%)$ occurred in the concrete with $80 \mathrm{~kg} / \mathrm{m}^{3}$ macro fiber content and limestone aggregate. When concrete produced with corundum and limestone aggregate is evaluated together, the weight loss occurred less in concrete with a high amount of macro steel fiber. According to the impact test results, it was concluded that the compressive strength does not have much effect on the impact strength after a certain strength limit, and the impact strength increases with the increase of fiber content. It has been determined that the increase in the amount of macro steel fiber has a direct effect on the impact effect.

Table 9. Impact resistance test results of samples.

\begin{tabular}{|c|c|c|c|c|}
\hline Mixture & $\begin{array}{c}\text { First Weight } \\
(\mathrm{gr})\end{array}$ & $\begin{array}{c}\text { Weight after 12 } \\
\text { hours (gr) }\end{array}$ & $\begin{array}{c}\text { Total weight loss } \\
\text { (gr) }\end{array}$ & $\begin{array}{c}\text { Weight percent } \\
\text { loss (\%) }\end{array}$ \\
\hline Limestone 1 & 16722 & 16053 & 669 & 4.0 \\
\hline Limestone 2 & 16664 & 16181 & 483 & 2.9 \\
\hline Corundum 1 & 18848 & 17434 & 1414 & 7.5 \\
\hline Corundum 2 & 19671 & 18432 & 1239 & 6.3 \\
\hline
\end{tabular}

\section{CONCLUSION}

In this study, the spread of the self-compacting concrete produced by using polycarboxylatebased plasticizer additive was adjusted to be at least $650 \mathrm{~mm}$. The segregation problem that may occur due to the high spread was solved by adjusting the amount of powder material (cement + calcite + blast furnace slag) to $700 \mathrm{~kg} / \mathrm{m}^{3}$. Compressive strengths of concrete with limestone aggregate were found to be 80.15 and $84.30 \mathrm{MPa}$, and compressive strengths of concrete with corundum aggregates were found to be 90.30 and $93.58 \mathrm{MPa}$. According to the abrasion test results, $0.65 \%$ and $0.60 \%$ weight loss occurred in concrete with limestone aggregate, while $0.38 \%$ and $0.36 \%$ weight loss occurred in corundum aggregate concrete. Corundum aggregate concrete gave better results than limestone aggregate concrete in terms of abrasion test. The abrasion resistance is high due to the hardness of the corundum aggregate being 9 according to the Mohs scale.

When concrete produced with limestone and corundum aggregate is subjected to impact test at the same time, 4 and $2.9 \%$ volume loss occurred in concrete with limestone aggregate, while 7.5 and 6.3 volume loss occurred in corundum aggregate concrete. With the increase in the amount of macro steel fiber ( $35 \mathrm{~mm}$ in length, $0.75 \mathrm{~mm}$ in diameter), the impact strength of concrete increased. With the 
increase in the length and diameter of the macro steel fiber, the bond length formed in the concrete increased, and the energy absorption capacity improved.

It was determined that the prepared concrete with limestone aggregate and $80 \mathrm{~kg} / \mathrm{m}^{3}$ macro steel fiber had the highest energy absorption capacity with 6296 joules in this study, and the weight loss was the least with $2.9 \%$ in the impact resistance test. Although the concrete produced with corundum aggregates increased the compressive strength and abrasion resistance, it was found that corundum aggregates did not affect the impact and energy absorption capacity much. In the load-deflection graphics, the first fractures and the first crack formation occurred in the cement paste. After the first crack formation, the load is placed on the fibers. In the creep test, it was revealed that the compressive strength of concrete samples was effective in the formation of the first cracks, while the fiber dosage was important in toughness and energy absorption capacity.

\section{REFERENCES}

ACI Committee 201. American Concrete Institute. Guide to Durable Concrete.

ASTM C944/C944M-19. 2019. Standard Test Method for Abrasion Resistance of Concrete or Mortar Surfaces by the Rotating-Cutter Method. ASTM International, West Conshohocken.

Banthia, N., Gupta, R. 2006. Influence of polypropylene fiber geometry on plastic shrinkage cracking in concrete. Cement and Concrete Research. 36: 1263-1267.

Banthia, N., Sappakittipakorn, M. 2007. Toughness enhancement in steel fiber reinforced concrete through fiber hybridization. Cement and Concrete Research. 37(9): 1366-1372.

Banthia, N., Zanotti, C., Sappakittipakorn, M. 2014. Sustainable fiber reinforced concrete for repair applications. Construction and Building Materials. 67: 405-412.

Bentur, A., Mindess, S. 2006. Fibre reinforced cementitious composites. 2nd Ed. Crc Press.

EN 12390-3. 2019. Testing hardened concrete- Part 3: Compressive strength of test specimens. Europeane Norm.

EN 12390-5. 2019. Testing hardened concrete- Part 5: Flexural strength of test specimens, Europeane Norm.

EN 14487-1. 2006. Sprayed Concrete- Part 1: Definitions, Specifications and Conformity. Europeane Norm.

EN 14488-5. 2006. Testing sprayed concrete. Part 5: Determination of energy absorption capacity of fibre reinforced concrete slab specimens. Europeane Norm.

Richard, P., Cheyrezy, M. 1995. Composition of reactive powder concretes. Cement and Concrete Research. 25(7): 1501-151.

South African Bureau of Standards: SANS 1058. 2012. South African National StandardConcrete paving blocks. pp. 1-17.

Wille, K., Kim. D.J., Naaman, A.E. 2011. Strain-hardening UHP-FRC with low fiber contents. Materials and Structures. 44(3): 583-598.

Wongprachum, W., Sappakittipakorn, M., Sukontasukkul, P., Chindaprasirt, P. and Banthia, N. 2018. Resistance to sulfate attack and underwater abrasion of fiber reinforced cement mortar. Construction and Building Materials. 189: 686-694. 
Yoo, D.Y., Banthia, N. 2017. Size-dependent impact resistance of ultra-high-performance fiberreinforced concrete beams. Construction and Building Materials. 142: 363-375.

Yoo, D.Y., Banthia, N., Fujikake, K., Borges, P.H., Gupta, R. 2017. Advanced Cementitious Materials: Mechanical Behavior, Durability, and Volume Stability. Advances in Materials Sciences and Engigeering. 1-2.

Yoo, D.Y., Banthia, N., Fujikake, K., Kim, Y.H., Gupta, R. 2019. Fiber-Reinforced Cement Composites: Mechanical Properties and Structural Implications. Advances in Materials Sciences and Engigeering. 1-2.

Yoo, D.Y., Zi, G., Kang, S.T., Yoon, Y.S. 2015. Biaxial flexural behavior of ultra highperformance fiber-reinforced concrete with different fiber lengths and placement methods. Cement and Concrete Composites. 63: 51-66. 